\title{
Botryosphaeriaceae Species Associated With Cankers and Dieback Symptoms of Acacia mangium and Pinus caribaea var. hondurensis in Venezuela
}

\author{
J. R. Úrbez-Torres, Summerland Research and Development Centre, Agriculture and Agri-Food Canada, Summerland, BC, V0H1Z0, \\ Canada; F. Castro-Medina, Centro Biotecnológico de Guayana, Universidad Nacional Experimental de Guayana, Venezuela, and Bio- \\ tecnología de Microorganismos, Facultad de Ciencias, Universidad de los Andes, Mérida, Venezuela; S. R. Mohali, Centro de Estudios \\ Forestales y Ambientales de Postgrado (CEFAP), Facultad de Ciencias Forestales y Ambientales, Universidad de los Andes, Mérida, Venezuela; \\ and W. D. Gubler, Department of Plant Pathology, University of California, Davis, CA 95616
}

\begin{abstract}
Úrbez-Torres, J. R., Castro-Medina, F., Mohali, S. R., and Gubler, W. D. 2016. Botryosphaeriaceae species associated with cankers and dieback symptoms of Acacia mangium and Pinus caribaea var. hondurensis in Venezuela. Plant Dis. 100:2455-2464.

Several species in the Botryosphaeriaceae family cause wood stain, cankers, and dieback of trunks and branches in a wide range of forest tree species. The aim of this study was to characterize the botryosphaeriaceous fungi associated with decline symptoms observed in Acacia mangium and Pinus caribaea var. hondurensis, two economically important forest tree species grown in commercial plantations in Venezuela. Fungi isolated from symptomatic samples collected from both hosts in commercial sites were identified based on their morphology and DNA sequences of the internal transcribed spacer region (ITS15.8S-ITS2) and part of the $\beta$-tubulin and translation elongation factor $1-\alpha$ genes. Lasiodiplodia theobromae and $L$. venezuelensis were routinely isolated from A. mangium and P. caribaea var. hondurensis. Additionally, the novel species Diplodia guayanensis was isolated and

characterized from symptomatic and asymptomatic tissues of A. mangium. Multigene phylogenetic analyses along with restriction fragment length polymorphism studies further supported the identification of these species. A pathogenicity study was conducted under natural conditions and 12 weeks after inoculation all Botryosphaeriaceae spp. were shown to be highly virulent on A. mangium. Contrary, no lesions were observed in the wood of $P$. caribaea var. hondurensis when inoculated with $L$. theobromae and $L$. venezuelensis. However, both species were consistently reisolated from the asymptomatic tissue beyond the inoculation point. This study contributes to a better understand the role that species in the Botryosphaeriaceae play on disease symptoms and dieback of $A$. mangium and $P$. caribaea var. hondurensis from plantations in eastern Venezuela.
\end{abstract}

Commercial forest plantations in Venezuela are primarily located in the eastern part of the country, where over 615,000 ha have been planted with the species Pinus caribaea var. hondurensis (Sénécl.) W.H.G. Barret \& Golfari since the mid-1970s. P. caribaea is of significant importance in Venezuela and plantations with this host provide more than $50 \%$ of the country's total round-wood production (ITTO 2005). Acacia mangium Willd. plantations were introduced in the early 1990s in Venezuela and occupy an area of approximately 120,000 ha (Briceño 2005). The primary purpose of these plantations is the production of wood and pulp, the latter being mainly used in the fabrication of paper, cardboard, and fiber agglomerates.

Botryosphaeriaceae Theiss. \& P. Syd. is a genus-rich family in the Dothideomycetes O. E. Erikss. \& Winka that includes endophytic, parasitic, and saprophytic species with a cosmopolitan distribution (Slippers and Wingfield 2007). Species in the Botryosphaeriaceae are plurivorous and several taxa from different genera are well-known pathogens of woody perennial crops and forest tree species causing a broad range of disease symptoms (Slippers et al. 2004; ÚrbezTorres 2011). Among these symptoms, perennial cankers in the vascular system are commonly observed and are probably the most important since they can kill large parts of the plant causing a rapid dieback, which often results in the eventual death of the host. Botryosphaeriaceae spp. are known to occur on a variety of forest tree species

Corresponding author: J. R. Úrbez-Torres:

E-mail: joseramon.urbeztorres@agr.gc.ca

J. R. Úrbez-Torres and F. Castro-Medina contributed equally to this work.

Accepted for publication 1 July 2016.

http://dx.doi.org/10.1094/PDIS-05-16-0612-RE

(C) Her Majesty the Queen in Right of Canada, as represented by the Minister of Agriculture and Agri-Food Canada worldwide and are of particular importance on Acacia and Pinus spp. (Jami et al. 2015; Mohali et al. 2007; Roux and Wingfield 1997). For instance, at least 18 Botryosphaeriaceae spp. have been described from native and nonnative Acacia spp. in South Africa with 13 of them occurring just in one host, A. karroo (Hayne) Banfi $\&$ Galasso, the most commonly occurring native tree in South Africa (Jami et al. 2012, 2015). Similarly, several botryosphaeriaceous taxa are known to cause cankers, tip blight, and shoot dieback in several Pinus spp. (Mohali et al. 2007; Swart and Wingfield 1991). Among them, Diplodia sapinea (Fr.) Fuckel and D. scrobiculata J. de Wet, Slippers \& M.J. Wingf. are well-known latent pathogens occurring in native and introduced Pinus spp. in the Northern and Southern Hemispheres, respectively (Bihon et al. 2011; Burgess et al. 2004).

Members of the Botryosphaeriaceae, including Diplodia mutila (Fr.) Mont., D. sapinea, Botryosphaeria dothidea (Moug. ex Fr.) Ces. \& De Not., and Lasiodiplodia theobromae (Pat.) Griffon \& Maubl. have long been known to occur in Venezuela, where they are commonly isolated from forest tree plantations and agriculture crops showing dieback symptoms (Cedeño et al. 1994; Mohali 1997; Mohali and Encinas 2001; Mohali et al. 2002, 2007, 2009). During the last decade, the introduction of DNA-based molecular identification approaches have significantly contributed to the characterization of other Botryosphaeriaceae spp. associated with cankers and vascular staining of Eucalyptus, Acacia, and Pinus spp. in commercial forest plantations of Venezuela, including Cophinforma mamane (D.E. Gardner) A.J.L. Phillips \& A. Alves, Neofusicoccum andinum (Mohali, Slippers \& M.J. Wingf.) Mohali, Slippers \& M.J. Wingf., N. parvum (Pennycook \& Samuels) Crous, Slippers \& A.J.L. Phillips, N. ribis (Slippers, Crous \& M.J. Wingf.) Crous, Slippers \& A.J.L. Phillips, L. crassispora T. Burgess \& Barber, L. pseudotheobromae A.J.L. Phillips, A. Alves \& Crous, L. venezuelensis T. Burgess, Barber \& Mohali, and Pseudofusicoccum stromaticum (Mohali, Slippers \& M.J. Wingf.) Mohali, Slippers \& M.J. Wingf. (Burgess et al. 2006; Castro-Medina et al. 2014; Mohali et al. 2006, 2007). However, these species have been primarily found in forest plantations located in central western states 
and in "Los Andes Cordillera" of Venezuela. Therefore, the aim of the present study is to further investigate the status of Botryosphaeriaceae spp. associated with decline symptoms observed in A. mangium and $P$. caribaea var. hondurensis, the two most prevalent tree species planted in eastern Venezuela, an area with over 700,000 ha of forest tree plantations of high economic value.

\section{Materials and Methods}

Sample collection and fungal isolation. Plant material was collected between 2009 and 2010 from forest tree plantations (Maderas del Orinoco C.A.) located in Uverito, Monagas State, Venezuela. Disease symptoms in A. mangium were primarily observed in the trunks and were characterized by light-brown cankers with a black exudate occurring in most of the affected trees. The most prevalent disease symptom observed in P. caribaea var. hondurensis was a blue stain of the wood, which was observed in fallen trees inside the plantations and in trees ready to be processed at the sawmill. In total, 30 A. mangium and $20 \mathrm{P}$. caribaea var. hondurensis samples from symptomatic trunks and branches were collected. Samples also included asymptomatic wood from both hosts. All samples were taken to the laboratory to perform isolations in order to identify the cankerand blue stain-causing organisms. Samples were first surface sterilized for $1 \mathrm{~min}$ in $1.5 \%$ sodium hypochlorite and then rinsed twice with sterile distilled water. Small pieces $\left(20\right.$ to $25 \mathrm{~mm}^{2}$ ) of both symptomatic (including the margin between cankered and healthy tissue) and asymptomatic wood tissue were placed on $2 \%$ potato dextrose agar (PDA) (Difco, BD Micro Biology Systems, Franklin Lakes, $\mathrm{NJ})$ petri plates supplemented with tetracycline hydrochloride $(0.01 \%)$ (Sigma-Aldrich, St. Louis, MO) (PDA-tet). Plates were sealed with Parafilm (Pechiney Plastic Packaging, Chicago, IL) and incubated at room temperature $\left(23 \pm 2^{\circ} \mathrm{C}\right)$ until fungal colonies were observed. Colonies resembling Botryosphaeriaceae spp. (fast growth, white or light green mycelium becoming dark green or olivaceous within few days) were selected and transferred to fresh PDA petri plates. Pure cultures were obtained by hyphal tip excision from the colony margins on PDA. These isolates are maintained in the Department of Plant Pathology fungal collection at the University of California, Davis. Type culture specimens were also deposited in the Centraalbureau voor Schimmelcultures (CBS) fungal collection, Utrecht, The Netherlands.

Morphological characterization. Representative isolates of the different colony types identified as potential Botryosphaeriaceae spp. from pure cultures were transferred to $2 \%$ water agar (Difco) petri plates containing double-autoclaved pine needles. Isolates were incubated at $25^{\circ} \mathrm{C}$ under continuous near-UV light to induce pycnidia formation and sporulation. Conidia morphological characteristics from pycnidia, including cell wall, shape, size, color, and presence of septum were recorded using light microscopy with a Leica DFC Camara Quick Start (Leica Microsystems Imaging Solutions Ltd, Cambridge, U.K.). The length and width of 60 conidia were measured for each taxon and minimum, maximum, mean, standard deviation, and 95\% confidence intervals were calculated using JMP Start Statistics software (SAS Institute, Cary, NC).

DNA extraction, PCR amplification, and sequencing. Total genomic DNA from selected Botryosphaeriaceae isolates was extracted from 8- to 10-day-old cultures using the DNeasy Plant Mini Kit (QIAGEN Inc, Valencia, CA). The internal transcribed spacer (ITS) region of the ribosomal RNA operon (ITS1-5.8S-ITS2), and part of the $\beta$-tubulin (BT) and translation elongation factor 1- $\alpha$ (TEF) genes were amplified using the ITS4/ITS5, Bt2a/Bt2b, and EF1-688F/EF11251R primer sets, respectively (Alves et al. 2008; Glass and Donaldson 1995; White et al. 1990). PCR reactions were carried out in a PTC100 thermal cycler (MJ Research, Watertown, MA) following the protocol and temperature profiles previously described (Alves et al. 2008; Úrbez-Torres et al. 2008). PCR products were separated by electrophoresis in $1.5 \%$ agarose gels stained with ethidium bromide and visualized under UV light. PCR amplicons were purified using the QIAquick PCR purification kit (QIAGEN Inc) and both forward and reverse strands of the ITS, BT, and TEF were sequenced using an ABI Prism 377 DNA Sequencer (Perkin-Elmer, Norwalk, CT) in the sequencing facility at the Division of Biological Sciences, University of California, Davis. Sequences were manually edited and assembled using Sequencher version 4.1 (Gene Codes, Ann Arbor, MI). Consensus sequences were BLASTed in GenBank to confirm species identity of each isolate and to identify homologous sequences in the database. Representative DNA sequences from each species identified in this study were deposited in GenBank.

Phylogenetic analyses. Fungal sequences were aligned using ClustalW multiple alignment program (Thompson et al. 1994). Manual adjustments of sequence alignment were carried out using BioEdit Sequence Alignment Editor Version 7.0.8 (Tom Hall). GenBank sequences from the different genera including ex-type specimens when possible were selected based on their high similarity with our query sequences using Mega BLAST (Table 1). A multilocus phylogenetic analysis was performed on the concatenated ITS, BT, and TEF datasets using maximum parsimony (MP) with the heuristic search option and the treebisection-reconnection (TBR) algorithm in MEGA6 (Tamura et al. 2013). Tree length, consistency index (CI), retention index (RI), and rescaled consistency index (RC) were calculated. The combined ITS, BT, and TEF dataset was further analyzed using the maximum composite likelihood (MCL) method based on the Tamura-Nei model. Tree topology with superior log likelihood value was selected. Bootstrap support was estimated using 1,000 replicates to assess the robustness of each clade in both MP and MLC phylogenetic methods.

PCR-RFLP analysis. A PCR-RFLP fingerprinting technique was applied to identify and group isolates of Botryosphaeriaceae from A. mangium and P. caribaea var. hondurensis that were not sequenced. TEF region sequence data were analyzed using Webcutter 2.0 (http:// rna.lundberg.gu.se/cutter2/) to identify polymorphisms of restriction enzyme sites among the different Botryosphaeriaceae spp. Part of the TEF locus was amplified from all isolates using primers EF1$688 \mathrm{~F} / \mathrm{EF} 1-1251 \mathrm{R}$ and amplicons were digested with the restriction enzyme (RE) $C f o I$. The RFLP reaction mixture consisted of $20 \mu \mathrm{l}$ RFLP of the PCR product, $0.30 \mu \mathrm{RE}$, and $2.5 \mu \mathrm{l}$ of the matching enzyme buffers. The mixture was incubated at $37^{\circ} \mathrm{C}$ overnight and the restriction fragments separated on $3 \%$ agarose gels (Chen et al. 2011). A standard 100 bp molecular marker was used to estimate the fragment size and gels were visualized as previously described.

Pathogenicity studies. A pathogenicity study was conducted under natural conditions using standing trees located in a commercial plantation (Maderas del Orinoco C.A.) in Monagas State, Venezuela. Field inoculations were carried out using two different isolates of each species isolated from symptomatic wood and identified by morphological and molecular studies (Table 1). The pathogenicity study was performed by inoculating the trunks of 2-year-old $A$. mangium and $P$. caribaea var. hondurensis trees $150 \mathrm{~cm}$ above the soil level. A 5-mm-diameter sterile metal cork borer was used to remove the bark and to expose the cambium layer. Five millimeter diameter mycelial discs from the growing margin of 8-day-old colonies were placed into an exposed wound with the mycelium facing the cambium. Inoculated wounds were sealed with Parafilm to protect them from desiccation and contamination. Ten trees per isolate $(60 \mathrm{~A}$. mangium and 40 P. caribaea var. hondurensis) were inoculated and 10 control trees per host were inoculated with noncolonized PDA plugs using the same technique. After 12 weeks, lesion length produced in the cambium from the inoculation point was measured to obtain an indication of the virulence of the isolates. Reisolation was done from the margins of the necrotic lesions as previously described and reisolated fungi were identified by comparing colony and conidial morphological characteristics to the original inoculated isolate. Differences in vascular discoloration length among isolates were determined using one-way analysis of variance (ANOVA) in SAS v. 8.1 (SAS Institute 2005). Treatment means were compared using Tukey's test at the 5\% significant level.

\section{Results}

Sample collection, fungal isolation, and morphological characterization. Seventy-five and 70 Botryosphaeriaceae-like isolates were obtained from either symptomatic or asymptomatic wood from A. mangium and P. caribaea var. hondurensis, respectively. Botryosphaeriaceae isolates from commercial plantations were first 
separated into two groups based on their appearance in culture and conidial morphology. The first group of isolates produced white mycelium, becoming gray to dark gray with age. Conidia from pycnidia developed on pine needles were ovoid, thick-walled, hyaline, and unicellular first, and turning dark brown with one-septum and longitudinal striations as they aged. The second group of isolates was initially characterized by a relatively slow growth white mycelium that became olivaceous in the center. Conidia from pycnidia were ovoid with ends broadly rounded, initially hyaline and unicellular, and becoming dark brown with 1 to 4 septa with age. These morphological characters were compared with those reported in previous studies (Phillips et al. 2013; Úrbez-Torres et al. 2008) and isolates from group one and two were tentatively identified to belong to the botryosphaeriaceous genera Lasiodiplodia Ellis \& Everh. and Diplodia Fr., respectively. Measurements taken from different isolates in the Diplodia group showed conidia size to be larger than the rest of the Diplodia species described in the literature (Table 2). Additionally, these conidia presented up to four septa, which has not been observed in any other Diplodia sp. While Lasiodiplodia and Diplodia isolates were identified from A. mangium, only Lasiodiplodia isolates were found in P. caribaea var. hondurensis.

DNA sequencing and phylogenetic analyses. DNA sequences and multilocus phylogenetic analyses allowed the identification of three different species in this study, including L. theobromae, L. venezuelensis, and a distinct Diplodia sp. that did not group with any described
Diplodia sp. from GenBank. The combined ITS, TEF, and BT phylogenetic analysis included 35 taxa with a total of 1,300 positions in the final dataset. MP analysis resulted in seven most parsimonious trees of which one is shown in Figure $1(\mathrm{TL}=702, \mathrm{CI}=0.676525$, $\mathrm{RI}=0.819170, \mathrm{RC}=0.667511)$. L. theobromae and $L$. venezuelensis isolates from A. mangium and $P$. caribaea var. hondurensis from Venezuela grouped in two separate well-supported clades (bootstrap value >98\%). Diplodia isolates CBS 129749, CBS 129750, and CBS129760 from A. mangium from Venezuela fell into a distinct well-supported clade (bootstrap value 97\%) and did not group with any known Diplodia sp. currently available in GenBank. These isolates were phylogenetically closely related to $D$. scrobiculata (Fig. 1).

PCR-RFLP analysis. A total of 66 Botryosphaeriaceae isolates that were not included in the phylogenetic study were identified by generating restriction maps using the RE $C f o$ I (Fig. 2A and B). PCR reactions using primers EF1-688F and EF1-1251R produced single amplicons between 246 and $262 \mathrm{bp}$. CfoI-digested amplicons produced four distinct profiles (Fig. 2A). Twenty-eight isolates represented L. theobromae (five from A. mangium and 23 from $P$. caribaea var. hondurensis), 16 isolates represented L. venezuelensis (seven from A. mangium and nine from $P$. caribaea var. hondurensis), seven isolates represented the previously identified species from $A$. mangium, L. pseudotheobromae (Castro-Medina et al. 2014), and 15 isolates represented a distinct Diplodia sp. from A. mangium (D. guayanensis). TEF sequence data from $D$. guayanensis from Venezuela showed

Table 1. Botryosphaeriaceae spp. included in this study for morphological studies, phylogenetic analyses, and pathogenicity tests

\begin{tabular}{|c|c|c|c|c|c|}
\hline \multirow[b]{2}{*}{ Species } & \multirow[b]{2}{*}{ Isolate $^{\mathbf{a}}$} & \multirow[b]{2}{*}{ Host/Origin/Collector } & \multicolumn{3}{|c|}{ GenBank accession numberb } \\
\hline & & & ITS & TEF & BT \\
\hline Diplodia africana & CBS120853 & Prunus persica/South Africa/U. Damm & EF445343 & EF445382 & KF766129 \\
\hline D. agrifolia & CBS132777 & Quercus agrifolia/U.S.A./S. C. Lynch \& A. Eskalen & JN693507 & JQ517317 & JQ411459 \\
\hline D. allocellula & CBS130408 & Acacia karroo/South Africa/F. Jami \& M. Gyzenhout & JQ239397 & JQ239384 & JQ239380 \\
\hline D. corticola & CBS112549 & Q. suber/Portugal/A. Alves & AY259100 & AY573227 & DQ458853 \\
\hline D. cupressi & CBS168.87 & Cupressus sempervirens/Israel/Z. Solel & DQ458893 & DQ458878 & DQ458861 \\
\hline D. guayanensis & CBS129749c & A. mangium/Venezuela/F. Castro-Medina \& S. R. Mohali & $J X 545106$ & $J X 545126$ & $J X 545146$ \\
\hline D. guayanensis & CBS129750 ${ }^{c}$ & A. mangium/Venezuela/F. Castro-Medina \& S. R. Mohali & JX545108 & $J X 545128$ & $J X 545148$ \\
\hline D. guayanensis & CBS129760 & A. mangium/Venezuela/F. Castro-Medina \& S. R. Mohali & JX545109 & JX545129 & $J X 545149$ \\
\hline D. mutila & CBS112553 & Vitis vinifera/Portugal/A. J. L. Phillips & AY259093 & AY573219 & JQ659295 \\
\hline D. olivarum & CBS121887 & Olea europaea/Italy/S. Frisullo & EU392302 & EU392279 & HQ660079 \\
\hline D. sapinea $(\mathrm{A})$ & CBS 393.84 & P. nigra/Netherlands/H. A. van der Aa & DQ458895 & DQ458880 & DQ458863 \\
\hline D. sapinea $(\mathrm{C})$ & CBS 109725 & P. patula/South Africa/M. J. Winfield & DQ458896 & DQ458881 & DQ458864 \\
\hline D. rosulata & CBS116470 & P. africana /Ethiopia/A. Gure & EU430265 & EU430267 & EU673132 \\
\hline D. scrobiculata & CMW 189 & P. banksiana/U.S.A./M. A. Palmer & AY253292 & AY624253 & AY624258 \\
\hline D. scrobiculata & CBS 109944 & P. greggii/Mexico/M. J. Wingfield & DQ458899 & DQ458884 & DQ458867 \\
\hline D. scrobiculata & CBS 113423 & P. greggii/Mexico/M. J. Wingfield & DQ458900 & DQ458885 & DQ458868 \\
\hline D. seriata & CBS112555 & V. vinifera/Portugal/A. J. L. Phillips & AY259093 & AY573219 & DQ458856 \\
\hline D. tsugae & CBS418.64 & Tsuga heterophylla/Canada/A. Funk & DQ458888 & DQ458873 & DQ458855 \\
\hline Lasiodiplodia crassispora & CBS110492 & Unknown/Unknown/Unknown & EF622086 & EF622066 & EU673134 \\
\hline L. missouriana & CBS128311 & V. vinifera/U.S.A./J. R. Úrbez-Torres & HQ288225 & HQ288267 & HQ288304 \\
\hline L. parva & CBS494.78 & Cassava-field soil/Colombia/O. Rangel & EF622084 & EF622064 & EU673114 \\
\hline L. pseudotheobromae & CBS447.62 & Citrus aurantium/Suriname/C. Smulders & EF622081 & EF622060 & EU673112 \\
\hline L. pseudotheobromae & CBS 116459 & Gmelina arborea/Costa Rica/J. Carranza-Velásquez & EF622077 & EF622057 & EU673111 \\
\hline L. pseudotheobromae & CBS129752 & A. mangium/Venezuela/F. Castro-Medina \& S. R. Mohali & $J X 545091$ & $J X 545111$ & $J X 545131$ \\
\hline L. pseudotheobromae & UCD-A1 & A. mangium/Venezuela/F. Castro-Medina \& S. R. Mohali & $J X 545092$ & $J X 545112$ & $J X 545132$ \\
\hline L. theobromae & CAA006 & V. vinifera/U.S.A./T. J. Michailides & DQ458891 & DQ458876 & DQ458859 \\
\hline L. theobromae & UCD-A28 & A. mangium/Venezuela/F. Castro-Medina \& S. R. Mohali & $J X 545095$ & $J X 545115$ & $J X 545135$ \\
\hline L. theobromae & $\mathrm{CBS} 129751^{\mathrm{c}}$ & A. mangium/Venezuela/F. Castro-Medina \& S. R. Mohali & $J X 545096$ & $J X 545116$ & $J X 545136$ \\
\hline L. theobromae & $\mathrm{CBS} 129754^{\mathrm{c}}$ & P. caribaea/Venezuela/F. Castro-Medina \& S. R. Mohali & JX545099 & JX545119 & $J X 545139$ \\
\hline L. venezuelensis & CBS118739 & A. mangium/Venezuela/S. R. Mohali & DQ377904 & EU673305 & EU673129 \\
\hline L. venezuelensis & CBS129753c & A. mangium/Venezuela/F. Castro-Medina \& S. R. Mohali & $J X 545100$ & $J X 545120$ & $J X 545140$ \\
\hline L. venezuelensis & UCD-P1 & P. caribaea/Venezuela/F. Castro-Medina \& S. R. Mohali & $J X 545103$ & $J X 545123$ & $J X 545143$ \\
\hline L. venezuelensis & $\mathrm{CBS} 129755^{\mathrm{c}}$ & P. caribaea/Venezuela/F. Castro-Medina \& S. R. Mohali & JX545104 & $J X 545124$ & $J X 545144$ \\
\hline L. venezuelensis & UCD-P13 & P. caribaea/Venezuela/F. Castro-Medina \& S. R. Mohali & JX545105 & JX545125 & $J X 545145$ \\
\hline L. viticola & CBS128313 & V. vinifera/U.S.A./J. R. Úrbez-Torres & HQ288227 & HQ288269 & HQ288306 \\
\hline Botryosphaeria dothidea & CMW 8000 & Prunus sp./Switzerland/B. Slippers & AY23949 & AY236898 & AY236927 \\
\hline Neofusicoccum parvum & CMW 9081 & Populus nigra/New Zealand/G. J. Samuels & AY236943 & AY236888 & AY236917 \\
\hline
\end{tabular}

\footnotetext{
${ }^{a}$ Isolate numbers in bold represent ex-type specimens.

${ }^{\mathrm{b}}$ Sequences in italics were generated in this study. ITS: Internal transcribed spacer (ITS1-5.8S-ITS2), TEF: translation elongation factor 1-alpha, BT: $\beta$-tubulin.

${ }^{\mathrm{c}}$ Isolates used in the pathogenicity study.
} 
different restriction patterns with CfoI enzyme using the Webcutter 2.0 program when compared with other phylogenetically closely related Diplodia spp. such as D. sapinea (B), D. scrobiculata, and D. intermedia, all of which showed the same restriction patterns (Fig. 2B). PCR-RFLP results along with the multilocus phylogenetic analysis and the observations recorded in the morphological study supported Diplodia isolates from A. mangium from Venezuela to be different from known species, and thus they are newly described in this study.

Taxonomy. Diplodia guayanensis. F. Castro-Medina, J. R. ÚrbezTorres, S. R. Mohali \& W. D. Gubler sp. nov. MycoBank: 812480 (Fig. 3).

Etymology. The name refers to the Guayana Region in Venezuela where this fungus was first collected.

Conidiomata. Pycnidia dark, submerged in agar or on the surface of pine needles, dark brown to black, covered with mycelium, single, (100-) 150 (-250) $\mu \mathrm{m}$ diameter, ostiole central, circular. Conidiogenous cells hyaline, discrete, spherical to cylindrical, holoblastic with limited proliferation precurrent, or proliferating at same level giving rise to periclinal thickenings. Conidia initially hyaline, becoming pigmented light brown to dark brown with age, unicellular to 1 to 4 septa, clavate to truncate, thick-walled, granular, (33.5-) 40.6 to $42.4(-56) \times$ (12-) 15.8 to $16.7(-18.5), n=60($ av. $\pm \mathrm{SD}=41 \pm 1.8 \times 16 \pm 1 \mu \mathrm{m}, \mathrm{L} / \mathrm{W}$ ratio $=2.5$ ).

Culture characteristics. Colonies on PDA with moderately dense mycelium, initially white turning light olive in the center within 8 days, and becoming dark olive with age, colonies with sinuate edges. Optimum temperature for colony growth at $25^{\circ} \mathrm{C}$.

Substrate. Acacia mangium.

Known distribution. Eastern Venezuela.

Holotype. Venezuela, Monagas, Uverito, isolated from trunk of A. mangium showing vascular discoloration of the wood in January 2010, F. Castro-Medina \& S. R. Mohali, ex-type culture CBS 129750.

Additional specimens examined. Venezuela, Monagas, Uverito, isolated from A. mangium showing vascular discoloration in the trunk in June 2010, F. Castro-Medina \& S. R. Mohali, CBS 129749, CBS 129760.

Notes. DNA sequence analyses revealed D. guayanensis to be closely related to $D$. scrobiculata. D. guayanensis can be distinguished from D. scrobiculata for having larger conidial size $(42 \times 16.5 \mu \mathrm{m}$ versus $39 \times 14 \mu \mathrm{m})$ (Table 2) and the presence of up to 4 septa (D. scrobiculata conidia mostly aseptate but up to 3 septa when present). D. guayanensis differs from $D$. sapinea (Fr.) Fuckel by the presence of septa.

Pathogenicity test. A. mangium trees inoculated with Botryosphaeriaceae isolates obtained from this host showed bark swelling around the inoculation points and necrosis of the vascular system below the bark 12 weeks after inoculation (Fig. 4A to C). Additionally, black exudation was observed when the outer bark was removed from inoculation points. D. guayanensis, $L$. theobromae, and $L$. venezuelensis isolates on A. mangium caused substantial vascular discoloration that ranged between 278.45 (CBS 129753) and $185.55 \mathrm{~mm}$ (CBS 129750) (Fig. 5). All three species were successfully reisolated from the lesions observed. On P. caribaea var. hondurensis, L. theobromae and L. venezuelensis caused lesions no different than the noncolonized PDA controls 12 weeks after inoculation (Figs. 4E and 5). However, both species were consistently reisolated from asymptomatic tissue approximately $2 \mathrm{~cm}$ beyond the necrotic wood observed around the inoculation point. A. mangium and $P$. caribaea var. hondurensis trees inoculated with noncolonized PDA showed no symptoms and the small necrotic lesions observed around the inoculation point represented wood reactions to the wound as none of the Botryosphaeriaceae spp. were reisolated from them (Fig. 4E).

\section{Discussion}

Morphological studies, DNA sequencing and multilocus phylogenetic analyses, RLFP fingerprinting, and pathogenicity studies allowed the identification and characterization of three Botryosphaeriaceae spp. from commercial forest plantations in eastern Venezuela. These species included $L$. theobromae and $L$. venezuelensis from both A. mangium and P. caribaea var. hondurensis and the novel species $D$. guayanensis from A. mangium.

Species within the Lasiodiplodia genus were the most common botryosphaeriaceous taxa isolated from commercial tree forest plantations in eastern Venezuela and among them, L. theobromae was the most prevalent fungus isolated from $A$. mangium trees showing cankers and dieback symptoms and from blue stain of the wood observed in $P$. caribaea var. hondurensis fallen trees and in log yards at sawmills. L. theobromae is a plurivorous ascomycete primarily found in temperate, tropical, and subtropical regions, where it has been reported to cause cankers, root and fruit rots, and leaf spots in a wide range of annual and perennial hosts, including both native and introduced Acacia and Pinus spp. (Farr and Rossman 2016; Punithalingam 1980).

Table 2. Comparison of conidial dimensions of Diplodia guayanensis against previously described Diplodia spp.

\begin{tabular}{|c|c|c|}
\hline Species & Conidial dimensions $(\mu \mathrm{m})$ & Reference \\
\hline D. africana & $(17-) 29.3(-34) \times(10-) 13(-15)^{a}$ [avg. $\left.29.2 \times 13\right]$ & Damm et al. 2007 \\
\hline D. agrifolia & $(21.5-) 27(-36.5) \times(12-) 14(5-18)^{\mathrm{a}}$ [avg. $\left.27.7 \times 14.7\right]$ & Lynch et al. 2013 \\
\hline D. alatafructa & (22.4-) 24.6 to $29.2(-32.9) \times(9.3-) 11.0$ to $13.8(-15.8)^{b}$ [avg. $\left.26.9 \times 12.4\right]$ & Mehl et al. 2011 \\
\hline D. allocellula & $(20-) 23.3(-30) \times(9-) 11.3(-14.5)^{\mathrm{a}}$ & Jami et al. 2012 \\
\hline D. bulgarica & $(22.5-) 25.5(-28) \times(14.5-) 16.8(-18.5)^{a}$ [avg. $\left.25.4 \times 16.8\right]$ & Phillips et al. 2013 \\
\hline D. corticola & $(23.5-) 26$ to $34.5(-46) \times(9-) 12$ to $16(-18.5)^{\mathrm{b}}$ [avg. $29.9 \times 13.6$ ] & Alves et al. 2004 \\
\hline D. cupressi & $(21.5-) 23.5$ to $28.5(-30.5) \times(12.0-) 13.5$ to $15.0(-16.0)^{\mathrm{b}}$ [avg. $\left.24.9 \times 14.2\right]$ & Alves et al. 2006 \\
\hline D. fraxini & $(26.5-) 29$ to $31.5(-33) \times(11-) 12.5$ to $14(-17.5)^{b}$ [avg. $29.8 \times 13.5$ ] & Alves et al. 2014 \\
\hline D. guayanensis & $(33.5-) 40.6$ to $42.4(56) \times(12-) 15.8$ to $16.7(-18.5)^{b}$ [avg. $\left.41.5 \times 16\right]$ & This study \\
\hline D. intermedia & $(24.6-) 29$ to $33.5(-36.9) \times(10-) 11$ to $16(-17.5)^{\mathrm{b}}[\mathrm{avg} .30 .6 \times 13.3]$ & Phillips et al. 2013 \\
\hline D. malorum & (24-) $29(-36) \times(12-) 15.5(-18.5)^{\mathrm{a}}$ [avg. $\left.28.1 \times 14.4\right]$ & Phillips et al. 2013 \\
\hline D. mutila & (23.5-) 24.5 to $27(-27.5) \times(12.5-) 13$ to $14(-14.5)$ [avg. $25.4 \times 13.4]$ & Phillips et al. 2013 \\
\hline D. neojuniperi & $(17-) 18$ to $21(-22) \times(9-) 10(-11)^{\mathrm{a}}$ & Trakunyingcharoen et al. 2015 \\
\hline D. olivarum & $(21.5-) 24.8(-28.5) \times(10-) 12.3(-14.5)^{\mathrm{a}}$ [avg. $\left.24.4 \times 12.4\right]$ & Phillips et al. 2013 \\
\hline D. sapinea & $(25.5-) 30.5$ to $52.5(-54) \times(10-) 12.5$ to $20(-21)^{\mathrm{b}}$ [avg. $\left.40.8 \times 15.5\right]$ & Palmer et al. 1987 \\
\hline D. pseudoseriata & (23-) 25.5 to $26.5(-30.5) \times(10-) 11.5$ to $12(-14)^{\mathrm{b}}$ & Pérez et al. 2010 \\
\hline D. quercivora & $(23-) 28(-30.5) \times(11.5-) 14(-14.5)^{\mathrm{a}}$ [avg. $\left.28.1 \times 13.8\right]$ & Linaldeddu et al. 2013 \\
\hline D. rosulata & $(21-) 28.5(-36) \times(10-) 14.3(-19.5)^{\mathrm{a}}$ [avg. $28 \times 14.5$ ] & Gure et al. 2005 \\
\hline D. scrobiculata & $(37.5-) 39.5(-41.5) \times(13-) 14(-15.5)^{\mathrm{a}}$ & de Wet et al. 2003 \\
\hline D. seriata & $(21.5-) 24.5(-28) \times(11-) 13(-15.5)$ [avg. $24.9 \times 12.9]$ & Phillips et al. 2013 \\
\hline D. tsugae & 36 to $41 \times 18$ to $22^{\mathrm{c}}$ & Phillips et al. 2013 \\
\hline
\end{tabular}

\footnotetext{
${ }^{\text {a }}$ Dimensions represent the mode with minimum and maximum in parenthesis.

${ }^{\mathrm{b}}$ Dimensions represent the lower and upper $95 \%$ confidence limits, with minimum and maximum in parenthesis.

${ }^{c}$ Dimensions represent the minimum and maximum.
} 
For instance, $L$. theobromae has been associated with symptomatic and/or asymptomatic wood tissues of A. cincinnata, A. crassicarpa, A. holosericea, and A. mangium in Brazil (Mendes et al. 1998); A. mearnsii and A. karroo in South Africa (Jami et al. 2015; Roux and Wingfield 1997); and A. mangium in Indonesia (Tarigan 2008; Tarigan et al. 2011). Furthermore, $L$. theobromae has been reported from P. caribaea in Brazil (Mendes et al. 1998), Honduras (Richardson
1990), and Nicaragua (Rees 1988); and from P. elliottii in Brazil (Maciel et al. 2015) and South Africa (Cilliers et al. 1995; Mohali et al. 2005). L. theobromae is widespread in Venezuela and has been associated with disease symptoms in over 100 plant hosts, including economic important horticultural crops such as citrus (Citrus aurantifolia and Citrus $\times$ sinensis) (Cedeño and Palacios-Pru 1992), coffee (Coffea arabica), mango (Mangifera indica), and papaya

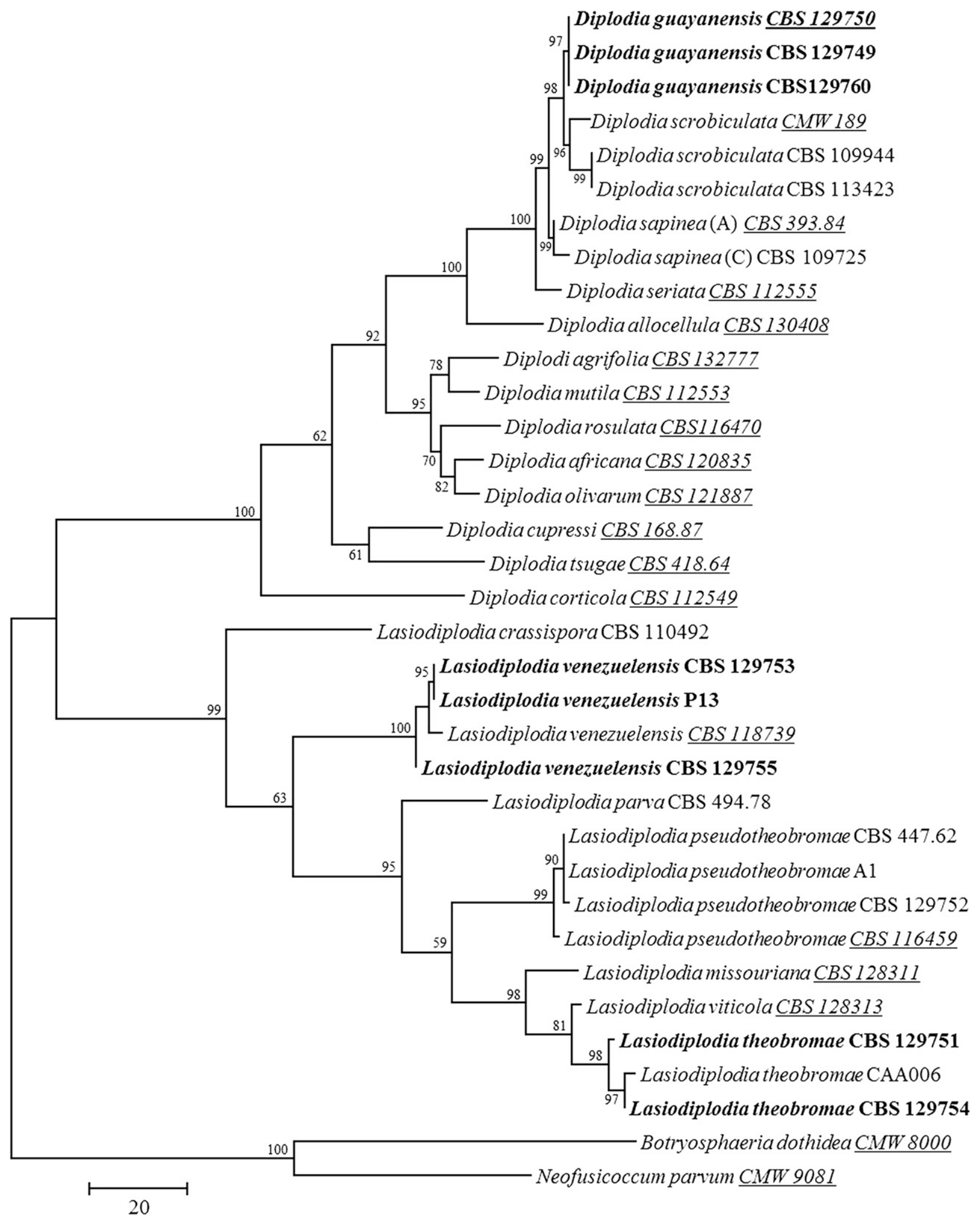

Fig. 1. One of seven equally parsimonious trees resulting from a total of total of 1,300 positions in the final ITS, BT, and TEF combined dataset. Tree length (TL) $=702$, consistency index $(\mathrm{Cl})=0.676525$, retention index $(\mathrm{RI})=0.819170$, retention composite index $(\mathrm{RC})=0.667511$. Isolates in bold represent Botryosphaeriaceae spp. isolated in this study. Isolates in italics and underline represent ex-type specimens. Bootstrap values with 1,000 replications are shown on branches for maximum parsimony (MP). 
(Carica papaya) (Farr and Rossman 2016). In Venezuela, L. theobromae has long been known to cause shoot blight and dieback of Pinus oocarpa Schiede ex Schltdl., blue stain of the wood of Caribbean pine ( $P$. caribaea), and it has been isolated from both symptomatic and asymptomatic tissues of Eucalyptus urophylla S.T. Bake $\times$ E. grandis Hill ex Maiden hybrids (Cedeño et al. 1996; Mohali et al. 2002, 2005 , 2007). Furthermore, and similar to the results obtain in the current study, previous surveys conducted throughout commercial forest

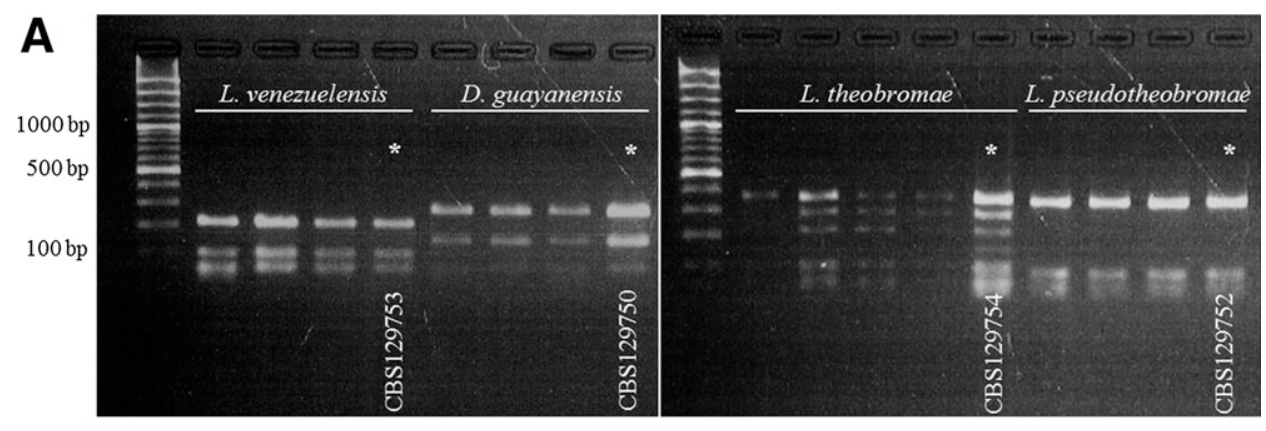

B

D. guayanensis (CBS 129750)
D. sapinea (A) (CBS 393.84)
D. sapinea(B) (CBS 109725)
D. scrobiculata (CBS 109944)
D. intermedia (JX152581)
L. theobromae (CBS 129754)
L. pseudotheobromae (CBS 129752)
L. Venezuelensis (CBS 129753)

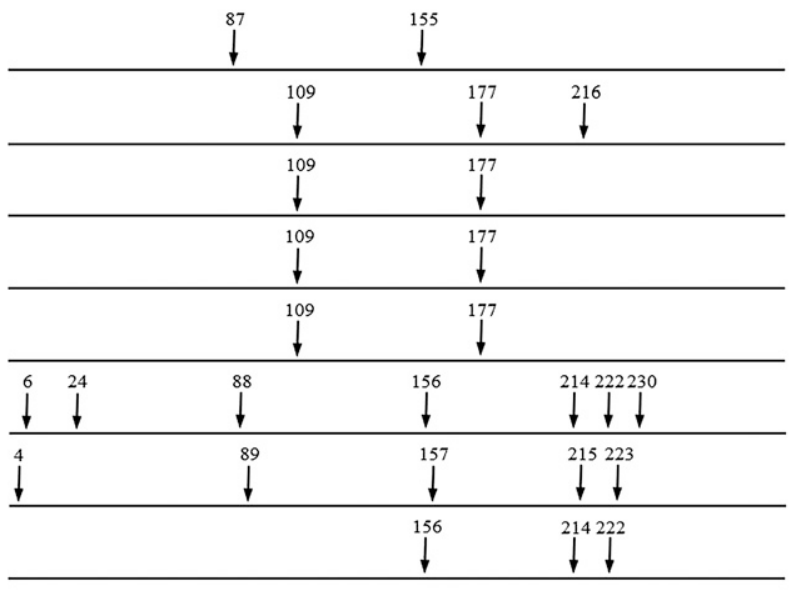

Fig. 2. Restriction fragment length polymorphism analyses. A, Agarose gel showing Cfol restriction fragments of translation elongation factor 1-alpha (TEF) PCR products of Diplodia guayanensis, Lasiodiplodia pseudotheobromae, L. theobromae, and L. venezuelensis from forest plantations in eastern Venezuela. Asterisks indicate positive controls of each species group. Molecular marker $=1,500 \mathrm{bp}$. B. Restriction maps for the restriction enzyme Cfol to the TEF locus of Botryosphaeriaceae spp. from Venezuela and closely related species. Fragments sizes (numbers indicate sizes in bp) were inferred from sequence data.

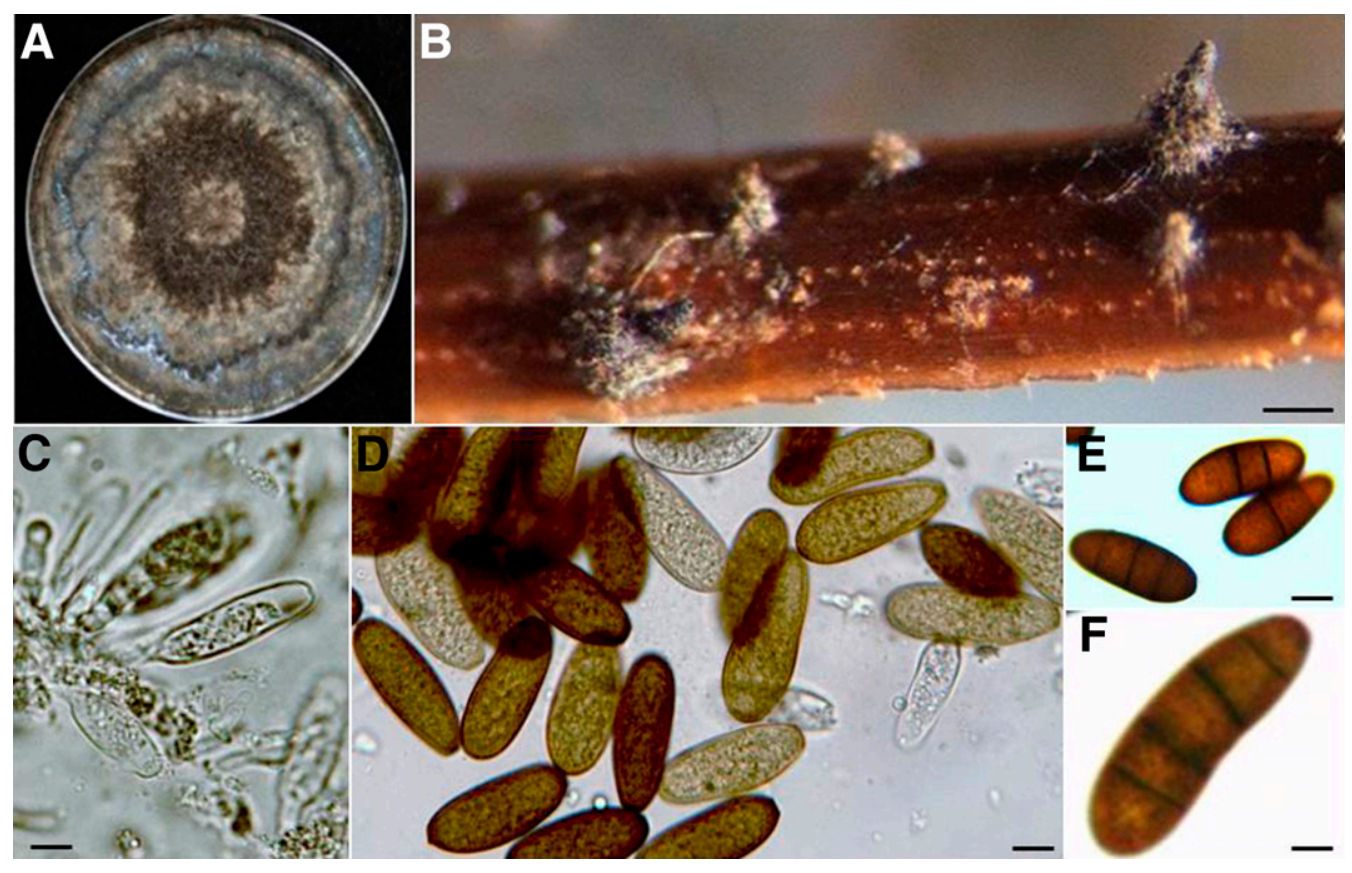

Fig. 3. Diplodia guayanensis isolate CBS 129750 macroscopic and microscopic phenotypic characteristics. A, Colony after 21 days on potato dextrose agar in 9-cm petri dish incubated at $20^{\circ} \mathrm{C}$. B, Pycnidia sporulating on autoclaved pine needles. C, Hyaline conidia developing on conideogenous cells. D, Unicellular, hyaline, and light-brown conidia. E, Mature dark-brown conidia with two and three septa. F, Mature conidia with four septa. Pictures of conidia were taken at 40x. Scale bars: $B=150 \mu \mathrm{m} ; C-E=15 \mu \mathrm{m} ; F=5 \mu \mathrm{m}$. 
plantations in the western states of Falcon, Portuguesa, and Cojedes showed $L$. theobromae to be the most prevalent fungus isolated from both A. mangium and P. caribaea var. hondurensis (Mohali et al. 2007). Though $L$. theobromae was already known to occur on these hosts in Venezuela, results from the current study are highly important as they show this species to also occur in eastern Venezuela. L. theobromae is known to significantly reduce the strength of low density tropical hardwoods and consequently has been shown to reduce wood value by up to $50 \%$ (Mohali et al. 2007). Therefore, L. theobromae could represent an important threat to wood production in eastern Venezuela, an economically important region with some of the largest commercial forest plantations in the country.

L. venezuelensis was the second most commonly isolated fungus in this study and was found in a similar number of samples collected from either A. mangium or P. caribaea var. hondurensis. L. venezuelensis was first described from A. mangium living wood tissue in the northwestern state of Portuguesa, Venezuela (Burgess et al. 2006). Compared with other Lasiodiplodia spp. and primarily to L. theobromae, the type species of the genus, L. venezuelensis has a restricted distribution as it has not been reported from elsewhere in the world to date. Results from this study show the distribution of L. venezuelensis to expand not only to forest plantations of $A$. mangium in eastern Venezuela but also to occur in a new host, P. caribaea var. hondurensis. L. pseudotheobromae was the least abundant Botryosphaeriaceae spp. found in this study and it was confirmed to only occur in A. mangium samples by RFLP patterns. L. pseudotheobromae was first described by Alves et al. (2008) and discovered as a cryptic species within L. theobromae using morphological and molecular data. Since then, this species is shown to have a cosmopolitan distribution and has been reported to cause cankers and dieback in over 70 different hosts (Farr and Rossman 2016), including horticultural crops such as citrus (Abdollahzadeh et al. 2010), coffee (Trakunyingcharoen et al. 2015), grapevines (Vitis vinifera L.) (Correia et al. 2016), mango (Marques et al. 2013), and papaya (Netto et al. 2014). Moreover, L. pseudotheobromae has also been associated with native and/or introduced tree species such as Eucalyptus grandis in Uruguay (Pérez et al. 2010), English walnut (Juglans regia) in China (Li et al. 2016), and Pterocarpus angolensis and Terminalia catappa in South Africa (Begoude et al. 2010; Mehl et al. 2011). With regard to Acacia spp., L. pseudotheobromae was first reported from trunk cankers of A. mangium in Venezuela and shown to be highly virulent in this host (Castro-Medina et al. 2014). Later, it was found to also occur in healthy wood tissues of A. karroo in South Africa, where pathogenicity studies indicated to be weakly virulent in this host (Jami et al. 2015). Results from the

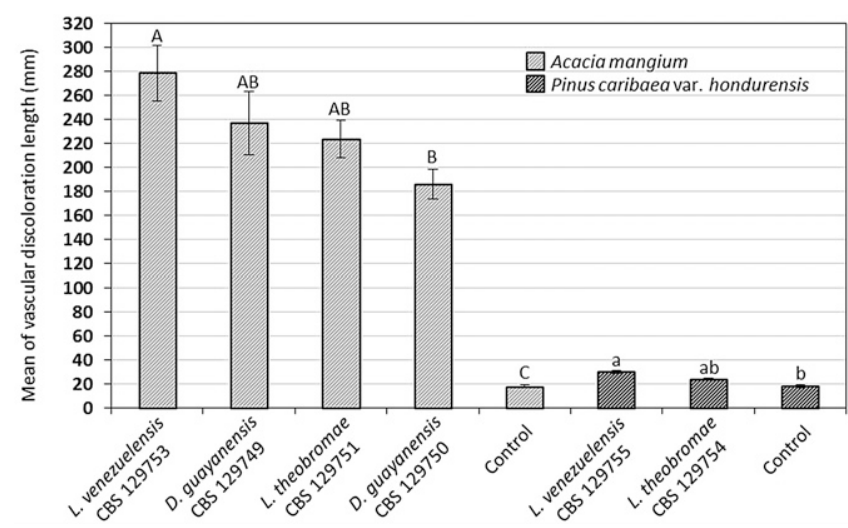

Fig. 5. Mean of vascular discoloration length 12 weeks after inoculation with Diplodia guayanensis, Lasiodiplodia theobromae, and $L$. venezuelensis in young Acacia mangium and Pinus caribaea var. hondurensis in a commercial plantation under natural conditions using fresh mycelium grown on agar medium. Control treatment was inoculated with noncolonized agar plugs. Mean lesion lengths followed by the same letter are not significantly different according to Tukey's test $(P=0.05)$. Bars represent standard error of the mean.

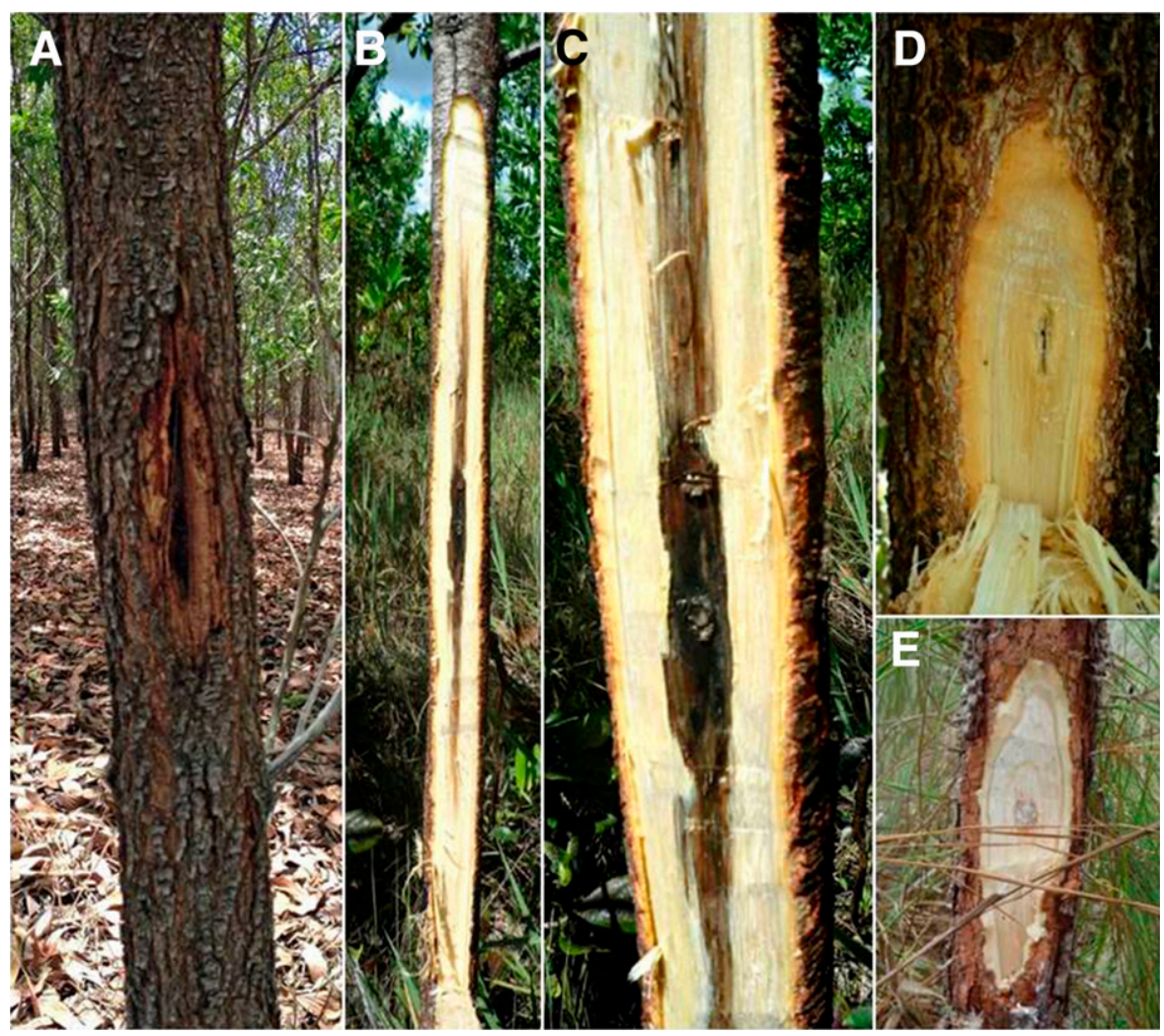

Fig. 4. Symptoms observed in Acacia mangium and Pinus caribaea var. hondurensis 12 weeks after inoculation. A, Bark swelling in A. mangium after inoculation with Diplodia guayanensis isolate CBS 129750. B and C, Vascular discoloration and necrotic wood tissue observed upward and downward the point of inoculation caused by $D$. guayanensis on A. mangium. D, No lesions were observed in $P$. caribaea var. hondurensis after inoculation with $L$. theobromae and $L$. venezuelensis. E, Control inoculations on $A$. mangium with malt extract agar plugs produced no lesions. 
current study suggest $L$. pseudotheobromae to have a broader distribution in forest plantations of $A$. mangium throughout Venezuela and hence, this species may play a more important role on $A$. mangium dieback than originally thought.

Morphological and molecular data obtained in this study supported the description of the novel species $D$. guayanensis from symptomatic wood tissues of A. mangium in Venezuela, which increases to 34 the total number of Diplodia spp. currently described and with DNA sequence data available in GenBank. D. guayanensis was shown to be morphologically and phylogenetically closely related to $D$. scrobiculata and to a lesser extent to D. sapinea. Morphologically, D. guayanensis presented the largest conidia of all known Diplodia spp. Additionally, most conidia from different isolates developed up to four septa, a morphological character not observed yet from any other described Diplodia sp. D. sapinea and D. scrobiculata conidia are mostly aseptate but when septa are present, they rarely formed one or three septa, respectively (Palmer et al. 1987). Though these characters appeared to be robust to discriminate among these species, morphological aspects among species in the Botryosphaeriaceae (primarily conidial size and septation) are known to be quite plastic and overlap depending on host and culture medium and thus, they need to be used with caution (Crous et al. 2006; Phillips et al. 2013). However, conidial size and septation have been widely used along with molecular data to discriminate among botryosphaeriaceous taxa, particularly among Diplodia spp. For instance, Lynch et al. (2013) showed that D. agrifolia S.C. Lynch \& A. Eskalen could be separated from its phylogenetically closely related species $D$. mutila (Fr.) Mont. by its larger and wider conidia. Similarly, D. allocellula Jami, Gryzenh, Slippers \& M.J. Wingf., morphologically very similar to D. seriata De Not., D. alatrafructa Mehl \& Slippers, and D. pseudoseriata C.A. Pérez, Blanchette, Slippers \& M.J. Wingf. can be distinguished from this species by having generally smaller conidia (Phillips et al. 2013). Furthermore, the smaller conidia and apparent preference for Rosaceae hosts can be used to discriminate between $D$. intermedia A.J.L. Phillips, J. Lopes \& A. Alves and its very closely related species D. sapinea (Phillips et al. 2013). Several Diplodia spp. and in particular D. sapinea and D. scrobiculata are well-known to occur as latent pathogens in Pinus spp. in different parts of the world (Burgess et al. 2004; de Wet et al. 2003; Punithalingam and Waterson 1970; Swart et al. 1985). Interestingly, D. guayanensis was only isolated from A. mangium and not from $P$. caribaea var. hondurensis in this study. Host specificity could be included as a distinguish feature for D. guayanensis; however, further investigations are still needed to support this trait. Despite phenotypical differences, species delimitation within most botryosphaeriaceous genera based solely on cultural and morphological characteristics is challenging. Thus, molecular analyses are nowadays being routinely used for species identification. In the current study, species discrimination was supported not only by morphological characters but also by phylogenetic studies and RFLP analyses. Moreover, RFLP analyses allowed us to determine the dominant Botryosphaeriaceae sp. (L. theobromae) occurring in forest plantations in eastern Venezuela. In the case of the novel species D. guayanensis, it formed a well-supported distinct clade in the phylogenetic tree and presented distinctive RFLP patterns when compared against its closely related species $D$. sapinea and $D$. scrobiculata. RFLP analyses have long been shown to successfully differentiate botryosphaeriaceous taxa within several genera (Mohali et al. 2007; Slippers et al. 2004). Additionally, RFLP is a rapid, robust, inexpensive, and user-friendly tool that can be used not only for species profiling but also in epidemiological studies to better understand species dominance and distribution.

Pathogenicity studies showed D. guayanensis, L. theobromae, and $L$. venezuelensis to be highly virulent on A. mangium. The current study also showed the presence of $L$. pseudotheobromae in symptomatic $A$. mangium trees in eastern Venezuela but this species was not included in the pathogenicity test as a similar study showed it recently to be very virulent on this host in Venezuela (Castro-Medina et al. 2014). Though L. venezuelensis was known to occur in A. mangium and P. caribaea var. hondurensis since mid-2000 in western Venezuela, its pathogenicity was not determined
(Burgess et al. 2006; Mohali et al. 2007). Accordingly, pathogenicity proof is shown for the first time in A. mangium, which resulted in L. venezuelensis to be the most virulent species among those tested in this study. L. theobromae has been known to occur in A. mangium in Brazil since the late 1990s (Mendes et al. 1998) and was first reported from this host in Venezuela in 2007 (Mohali et al. 2007). Recently, $L$. theobromae has been reported, along with Ceratocystis acaciivora Tarigan \& M. van Wyk, as the main cause of death of young A. mangium trees in central Sumatra, Indonesia (Tarigan 2008; Tarigan et al. 2011). These latter results are in agreement with the pathogenicity scores obtained in the current study, which showed L. theobromae to be also very virulent in A. mangium in young trees in Venezuela. Similar to our results, a recent study also showed $L$. theobromae to be the most virulent botryosphaeriaceous species in A. karroo, a different species within the same family, in South Africa (Jami et al. 2015). The results obtained in the current study are of significant importance and confirm $L$. theobromae and $L$. venezuelensis, two widely spread species in Venezuela, as a major threat to A. mangium plantations in the country. Additionally, the novel species $D$. guayanensis is shown to also play an important role in the health status of this host in Venezuela. Interestingly, both $L$. venezuelensis and $L$. theobromae did not cause lesions when inoculated in P. caribaea var. hondurensis, but they were routinely reisolated from asymptomatic wood, which may indicate the latent pathogen status of these species in this host. It is well known that several species in the Botryosphaeriaceae family are latent pathogens residing asymptomatically in tree hosts for long periods of time until stress conditions turn them in aggressive pathogens (Jami et al. 2013, Slippers and Wingfield 2007). This has long been demonstrated with species such as $B$. dothidea, D. sapinea, and D. scrobiculata in Pinus spp. (Burgess et al. 2004; Flowers et al. 2003; Smith et al. 1996; Stanosz et al. 1995). Recently, Jami et al. (2015) identified 13 Botryosphaeriaceae spp. from healthy tissues of A. karroo in South Africa, including L. theobromae, which clearly showed this species to occur as a latent pathogen in this host. L. theobromae has been reported to occur asymptomatically in Pinus spp. seedlings in nurseries in Brazil (Maciel et al. 2015) and South Africa (Cilliers et al. 1995), which has been highlighted as a potential source for introduction of infected trees into forest plantations. However, and contrary to what we know in other forest tree hosts, there is still a lack of information about the status of Lasiodiplodia spp. as latent pathogens in Pinus spp. Forestry is still one of the most important economic engines in Venezuela. However, no studies have been conducted to determine the potential threat that Botryosphaeriaceae spp. may have as latent pathogens within plantations of exotic or introduced forest tree species in Venezuela.

The results of this study show the relevant role that Botryosphaeriaceae spp., including the newly described $D$. guayanensis, play on the health status of the two most important forest tree species grown in commercial plantations in Venezuela and adds newly information on the occurrence of L. venezuelensis as latent pathogens in $P$. caribaea var. hondurensis. Accordingly, this study provides the foundation to further investigate the impact, biology, and epidemiology of these fungi in forest plantations in Venezuela with the aim to develop and implement effective management strategies.

\section{Acknowledgments}

The authors thank the company Maderas del Orinoco for its collaboration during this research project by providing access to commercial plantations to collect samples and conduct pathogenicity studies.

\section{Literature Cited}

Abdollahzadeh, J., Jvadi, A., Mohammadi-Goltapeh, E., Zare, R., and Phillips, A. J. L. 2010. Phylogeny and morphology of four new species of Lasiodiplodia from Iran. Persoonia 25:1-10.

Alves, A., Correia, A., Luque, J., and Phillips, A. 2004. Botryosphaeria corticola sp. nov. On Quercus species, with notes and description of Botryosphaeria stevensii and its ana- morph, Diplodia mutila. Mycologia 96:598-613.

Alves, A., Correia, A., and Phillips, A. J. L. 2006. Multi-gene genealogies and morphological data support Diplodia cupressi sp. nov., previously recognized as $D$. pinea $\mathrm{f}$. sp. cupressi, as a distinct species. Fungal Divers. $23: 1-15$ 
Alves, A., Crous, P. W., Correia, A., and Phillips, A. J. L. 2008. Morphological and molecular data reveal cryptic species in Lasiodiplodia theobromae. Fungal Divers. 28:1-13.

Alves, A., Linaldeddu, B. T., Deidda, A., Scanu, B., and Phillips, A. J. L. 2014. The complex of Diplodia species associated with Fraxinus and some other woody hosts in Italy and Portugal. Fungal Divers. 67:143-156.

Begoude, B. A., Slippers, B., Wingfield, M., and Roux, J. 2010. Botryosphaeriaceae associated with Terminalia catappa in Cameroon, South Africa and Madagascar. Mycol. Prog. 9:101-123.

Bihon, W., Slippers, B., Burgess, T., Wingfield, M. J., and Wingfield, B. D. 2011. Diplodia scrobiculata found in the southern hemisphere. For. Pathol. 41: 175-181.

Briceño Méndez, M. 2005. Informe Nacional Venezuela. Estudio de tendencias y perspectivas del Sector Forestal en América Latina. Food and Agriculture Organization of the United Nations (FAO), Rome. Online publication retrieved 1 May 2016 from http://www.fao.org/docrep/008/j5484s/j5484s00. htm\#TopOfPage

Burgess, T. I., Barber, P. A., Mohali, S., Pegg, G., de Wet, B., and Wingfield, M. J. 2006. Three new Lasiodiplodia spp. from the tropics, recognized based on DNA sequence comparisons and morphology. Mycologia 98:423-435.

Burgess, T. I., Gordon, T. R., Wingfield, M. J., and Wingfield, B. D. 2004. Geographical isolation of Diploida scrobiculata and its association with native Pinus radiata. Mycol. Res. 108:1399-1406.

Castro-Medina, F., Mohali, S. R., Úrbez-Torres, J. R., and Gubler, W. D. 2014. First report of Lasiodiplodia pseudotheobromae causing trunk cankers in Acacia mangium in Venezuela. Plant Dis. 98:686.

Cedeño, L., Mohali, S. R., and Carrero, C. 1994. Primer reporte en Venezuela de Dothiorella dothidea como la causa de la podredumbre marrón en frutos del duraznero. Fitopat. Venez. 7:34-36

Cedeño, L., Mohali, S. R., and Palacios-Pru, E. 1996. Ultrastructure of Lasiodiplodia theobromae causal agent of Caribbean pine blue stain in Venezuela. Interciencia 21:264-271.

Cedeño, L., and Palacios-Pru, E. 1992. Identificación de Botryodiplodia theobromae como la causa de las lesiones y gomosis en cítricos. Fitopat. Venez. 5:10-13.

Chen, S. F., Pavlic, D., Roux, J., Slippers, B., Xie, Y. J., Wingfield, M. J., and Zhou, X. D. 2011. Characterization of Botryosphaeriaceae from plantationgrown Eucalyptus species in South China. Plant Pathol. 60:739-751.

Cilliers, A. J., Swart, W. J., and Wingfield, M. J. 1995. The occurrence of Lasiodiplodia theobromae on Pinus elliottii seeds in South Africa. Seed Sci. Technol. 23:851-860.

Correia, K. C., Silva, M. A., de Morais, M. A., Jr., Armengol, J., Phillips, A. J. L., Camara, M. P. S., and Michereff, S. J. 2016. Phylogeny, distribution and pathogenicity of Lasiodiplodia species associated with dieback of table grape in the main Brazilian exporting region. Plant Pathol. 65:92-103.

Crous, P., Slippers, B., Wingfield, M., Rheeder, J., Marasas, W., Philips, A., Alves, A., Burgess, T., Barber, P., and Groenewald, J. 2006. Phylogenetic lineages in the Botryosphaeriaceae. Stud. Mycol. 55:235-253.

Damm, U., Crous, P. W., and Fourie, P. H. 2007. Botryosphaeriaceae as potential pathogens of Prunus species in South Africa, with descriptions of Diplodia africana and Lasiodiplodia plurivora sp. nov. Mycologia 99: 664-680.

de Wet, J., Slippers, B., Preisig, O., Wingfield, B. D., and Wingfield, M. J. 2003. Multiple gene genealogies and microsatellite markers reflect relationships between morphotypes of Sphaeropsis sapinea and distinguish a new species of Diplodia. Mycol. Res. 107:557-566.

Farr, D. F., and Rossman, A. Y. 2016. Fungal Databases, Syst. Mycol. Microbiol. Lab., ARS, USDA. Retrieved 15 January 2016 from http://nt.ars-grin.gov/ fungaldatabases/fungushost/fungushost.cfm

Flowers, J., Hartman, J., and Vaillancourt, L. 2003. Detection of latent Sphaeropsis sapinea infections in Austrian pine tissues using nested-polymerase chain reaction. Phytopathology 93:1471-1477.

Glass, L. N., and Donaldson, G. C. 1995. Development of primer sets designed for use with the PCR to amplify conserved genes from filamentous Ascomycetes. Appl. Environ. Microbiol. 61:1323-1330.

Gure, A., Slippers, B., and Stenlid, J. 2005. Seed-borne Botryosphaeria spp. from native Prunus and Podocarpus trees in Ethiopia, with a description of the anamorph Diplodia rosulata sp. nov. Mycol. Res. 109:1005-1014.

International Tropical Timber Organization (ITTO). 2005. Status of Tropical Forest Management 2005, Venezuela. Online publication retrieved 1 May 2016 from http://www.itto.int/sfm_detail/id=12590000

Jami, F., Slippers, B., Wingfield, M. J., and Gryzenhout, M. 2012. Five new species of the Botryosphaeriaceae from Acacia karroo in South Africa. Cryptogam., Mycol. 33:245-266.

Jami, F., Slippers, B., Wingfield, M. J., and Gryzenhout, M. 2013. Botryosphaeriaceae diversity greater in healthy than associated diseased Acacia karroo tree tissue. Australas. Plant Pathol. 42:421-430.

Jami, F., Slippers, B., Wingfield, M. J., Loots, M. T., and Gryzenhout, M. 2015. Temporal and spatial variation of Botryosphaeriaceae associated with Acacia karroo in South Africa. Fungal Ecol. 15:51-62.

Li, G. Q., Liu, F. F., Li, J. Q., Liu, Q. L., and Chen, S. F. 2016. Characterization of Botryosphaeria dothidea and Lasiodiplodia pseudotheobromae from English walnut in China. J. Phytopathol. 164:348-353.
Linaldeddu, B. T., Franceschini, A., Alves, A., and Phillips, A. J. L. 2013. Diplodia quercivora sp. nov.: a new species of Diplodia found on declining Quercus canariensis trees in Tunisia. Mycologia 105:1266-1274.

Lynch, S. C., Eskalen, A., Zambino, P. J., Mayorquin, J. S., and Wang, D. H. 2013 Identification and pathogenicity of Botryosphaeriaceae species associated with coast live oak (Quercus agrifolia) decline in southern California. Mycologia 105:125-140.

Maciel, C. G., Muniz, M. F. B., Mezzomo, R., and Reiniger, L. R. S. 2015 Lasiodiplodia theobromae associated with seeds of Pinus spp. originated from the northwest of Rio Grande do Sul, Brazil. Sci. Forum 43: 639-646.

Marques, M. W., Lima, N. B., de Morais, M. A., Jr., Barbosa, M. A. G., Souza, B. O., Michereff, S. J., Phillips, A. J. L., and Camara, M. P. S. 2013. Species of Lasiodiplodia associated with mango in Brazil. Fungal Divers. 61:181-193.

Mehl, J. W. M., Slippers, B., Roux, J., and Wingfield, M. J. 2011. Botryosphaeriaceae associated with Pterocarpus angolensis (kiaat) in South Africa. Mycologia 103 534-553.

Mendes, M. A. S., da Silva, V. L., Dianese, J. C., Ferreira, M. A. S. V., dos Santos, C. E. N., Neto, E. G., Urben, A. F., and Castrp, C. 1998. Fungos em Plants no Brasil. Embrapa-SPI/Embrapa-Cenargen, Brasilia, Brazil.

Mohali, S., Slippers, B., and Wingfield, M. J. 2006. Two new Fusicoccum spp from Eucalyptus and Acacia in Venezuela, based on morphology and DNA sequence data. Mycol. Res. 110:405-413.

Mohali, S. R. 1997. Primer reporte en Venezuela de Sphaeropsis sapinea, agente causal del manchado azul del Pino Caribe. Fitopatol. Venez. 10:23.

Mohali, S. R., Burgess, T. I., and Wingfield, M. J. 2005. Diversity and host association of the tropical tree endophyte Lasiodiplodia theobromae revealed using simple sequence repeat markers. For. Pathol. 35:385-396.

Mohali, S. R., and Encinas, O. 2001. Association of Diplodia mutila with blue stain of Caribbean pine in Venezuela. For. Pathol. 31:187-189.

Mohali, S. R., Encinas, O., and Mora, N. 2002. Manchado azul en madera de Pinus oocarpa y Azadirachta indica en Venezuela. Fitopatol. Venez. 15:30-32.

Mohali, S. R., Slippers, B., and Wingfield, M. J. 2007. Identification of Botryosphaeriaceae from Eucalyptus, Acacia and Pinus in Venezuela. Fungal Divers. 25:143-165.

Mohali, S. R., Slippers, B., and Wingfield, M. J. 2009. Pathogenicity of seven species of the Botryosphaeriaceae on Eucalyptus clones in Venezuela. Australas. Plant Pathol. 38:135-40.

Netto, M. S. B., Assuncao, I. P., Lima, G. S. A., Marques, M. W., Lima, W. G., Monteiro, J. H. A., Michereff, S. J., Phillips, A. J. L., Camara, M. P. S., and de Queiroz Balbino, V. 2014. Species of Lasiodiplodia associated with papaya stem-end rot in Brazil. Fungal Divers. 67:127-141.

Palmer, M. A., Steward, E. L., and Wingfield, M. J. 1987. Variation among isolates of Sphaeropsis sapinea in the North Central United States. Phytopathology 77: 944-948.

Pérez, C. A., Wingfield, M. J., Slippers, B., Altier, N. A., and Blanchette, R. A 2010. Endophytic and canker-associated Botryosphaeriaceae occurring on non-native Eucalyptus and native Myrtaceae trees in Uruguay. Fungal Divers. 41:53-69.

Phillips, A. J. L., Alves, A., Abdollahzadeh, J., Slippers, B., Wingfield, M. J., Groenewald, J. Z., and Crous, P. W. 2013. The Botryosphaeriaceae: genera and species known from culture. Stud. Mycol. 76:51-167.

Punithalingam, E. 1980. Plant Diseases Attributed to Botryodiplodia theobromae (Bibliotheca Mycologica). J. Cramer, Berlin.

Punithalingam, E., and Waterston, J. M. 1970. Diplodia pinea. Descriptions of pathogenic fungi and bacteria, No. 273. Commonwealth Mycological Institute, Kew, Surrey, U.K.

Rees, A. A. 1988. Infection of Pinus caribaea seed by Lasiodiplodia theobromae. Trans. Br. Mycol. Soc. 90:321-324.

Richardson, M. J. 1990. An annotated list of seed-borne diseases, 4th Ed. International Seed Testing Association, Zurich, Switzerland.

Roux, J., and Wingfield, M. J. 1997. Survey and virulence of fungi occurring on diseased Acacia mearnsii in Sout Africa. For. Ecol. Manage. 99:327-336.

SAS Institute. 2005. JMP ${ }^{\circledR}$ Start Statistics third edition. A guide to statistics and data analysis using JMP and JMP software. SAS Institute Inc., Cary, NC.

Slippers, B., Fourie, G., Crous, P. W., Coutinho, T. A., Wingfield, B. D., Carnegie, A. J., and Wingfield, M. J. 2004. Speciation and distribution of Botryosphaeria spp. on native and introduced Eucalyptus trees in Australia and South Africa. Stud. Mycol. 50:343-358.

Slippers, B., and Wingfield, M. J. 2007. Botryosphaeriaceae as endophytes and latent pathogens of woody plants: Diversity, ecology and impact. Fungal Biol. Rev. 21:90-106.

Smith, H., Wingfield, M. J., Crous, P. W., and Couthino, T. A. 1996. Sphaeropsis sapinea and Botryosphaeria dothidea endophytic in Pinus spp. and Eucalyptus spp. in South Africa. S. Afr. J. Bot. 62:86-88.

Stanosz, G. R., Smith, D. R., Guthmiller, M. A., and Stanosz, J. C. 1995 Persistance of Sphaeropsis sapinea on or in asymptomatic stems of red pine nursery seedlings. Phytopathology 85:1196.

Swart, W. J., and Wingfield, M. J. 1991. Biology and control of Sphaeropsis sapinea on Pinus species in South Africa. Plant Dis 75:761-766.

Swart, W. J., Wingfield, M. J., and Knox-Davies, P. S. 1985. Sphaeropsis sapinea, with special reference to its occurrence on Pinus spp. in South Africa. S. Afr. For. J. 35:1-8. 
Tamura, K., Stecher, G., Peterson, D., Filipski, A., and Kumar, S. 2013. MEGA6: Molecular evolutionary genetics analysis version 6.0. Mol. Biol. Evol. 30:2725-2729. Tarigan, M. 2008. Ceratocystis spp. and Botryosphaeriaceae on plantation Acacia species in Central Sumatra, Indonesia. MSc Thesis, University of Pretoria, South Africa.

Tarigan, M., Wingfield, M. J., van Wyk, M., Tjahjono, B., and, Roux, J. 2011. Pruning quality affects infection of Acacia mangium and A. crassicarpa by Ceratocystis acaciivora and Lasiodiplodia theobromae. South. For. 73: 187-191.

Thompson, J. D., Higgins, D. G., and Gibson, T. J. 1994. CLUSTAL W: improving the sensitivity of progressive multiple sequence alignment through sequence weighting, position-specific gap penalties and weight matrix choice. Nucleic Acids Res. 22:4673-4680.
Trakunyingcharoen, T., Lombard, L., Groenewald, J. Z., Cheewangkoon, R., To-anun, C., and Crous, P. W. 2015. Caulicolus Botryosphaeriales from Thailand. Persoonia 34:87-99.

Úrbez-Torres, J. R. 2011. The status of Botryosphaeriaceae spp. infecting grapevines. Phytopathol. Mediterr. 50:S5-S45.

Úrbez-Torres, J. R., Leavitt, G. M., Guerrero, J. C., Guevara, J., and Gubler, W. D. 2008. Identification and pathogenicity of Lasiodiplodia theobromae and Diplodia seriata, the causal agents of bot canker disease of grapevines in Mexico. Plant Dis. 92:519-529.

White, T. J., Bruns, T., Lee, S., and Taylor, J. 1990. Amplification and direct sequencing of fungal ribosomal RNA genes for phylogenetics. Pages 315-322 in: PCR Protocols: A Guide to Methods and Applications. M. A. Innis, D. H. Gelfand, J. J. Snisky, and T. J. White, eds. Academic Press, San Diego, CA. 